\title{
On the Outside Looking In: The Precarious Housing Situations of Successful Refugee Claimants in the GVRD
}

\author{
Kathy Sherrell, Silvia D’Addario, and Daniel Hiebert
}

\begin{abstract}
Access to affordable and adequate housing is a key step in the successful integration of newcomers. While some immigrants are able to transition into home ownership quite rapidly, other newcomers are finding it increasing difficult to access basic shelter. There is little systematic knowledge about the extent of homelessness among immigrants and refugees in Greater Vancouver. This paper details the findings of a 2005 study entitled The Profile of Absolute and Relative Homelessness among Immigrants, Refugees, and Refugee Claimants in the GVRD. We highlight the extent to which some newcomers are increasingly at risk of "hidden homelessness," a term that describes precarious and unstable housing experiences. This paper also details the unique housing experiences of refugee claimants. Given their temporary legal status, claimants often face the most tenuous experiences in the housing market. Their experiences are often marked by poor residential conditions, crowding, and high rent-to-income ratios.
\end{abstract}

\section{Résumé}

L'accès à un logement abordable et adéquat est une étape importante dans l'intégration réussie des nouveaux arrivants. Bien que quelques immigrants parviennent à devenir propriétaire de leur logement assez rapidement, d'autres nouveaux arrivants éprouvent des difficultés croissantes pour accéder à un abri de base. Il existe peu d'information systématique sur l'étendue du phénomène des sans-abris parmi les immigrants et les réfugiés dans le Grand Vancouver. Ce document met en exergue les résultats d'une étude entreprise en 2005 et intitulée The Pro- file of Absolute and Relative Homelessness Among Immigrants, Refugees, and Refugee Claimants in the GVRD ("Le profil des sans-abris absolus et relatifs parmi des immigrants, les réfugiés, et les demandeurs du statut de réfugiés dans le DRGV"). Nous soulignons la mesure dans laquelle certains nouveaux arrivants sont de plus en plus à risque du sans-abrisme caché, un terme qui décrit des expériences de logement précaire et instable. Ce document détaille également les expériences uniques en matière de logement des demandeurs du statut de réfugié. Étant donné leur statut juridique provisoire, les demandeurs font face souvent à des expériences des plus ardues sur le marché du logement. Leurs expériences sont souvent caractérisées par des conditions de logement précaires, l'encombrement et des loyers élevés par rapport aux revenus.

\section{Introduction}

the longer a problem is ignored, the bigger it becomes...

— sign on the side of Covenant House Vancouver

On any given day media headlines inundate readers with stories about Vancouver's housing market: "Vancouver real estate prices lead the Nation," "Real estate prices rise 11.2\% in year," "Housing prices continue to climb"; Vancouver continues to be the most expensive real estate market in Canada. ${ }^{1}$ In January 2007 the average house sold for $\$ 530,695$ (an increase of 16 per cent over the same period last year) compared to the national average of $\$ 299,318$, making the housing ownership market increasingly difficult to enter for the average Vancouver household. ${ }^{2}$ Tenants face 
similar difficulties in accessing housing: Vancouver has the second highest rents in the country, with the majority of units in the private rental market. At the same time, recent research warns about the decreased economic fortunes of newcomers - as evidenced by longer catch-up times and lower wages. ${ }^{3}$ "The New Face of Poverty" screams a January 2007 Globe and Mail headline: according to a report released by Statistics Canada educated and skilled immigrants have become the new face of poverty in Canada. ${ }^{4}$ For refugees, who constitute a much smaller proportion of newcomers, the findings are grim: refugees are more likely to experience chronic low income and much less likely to exit poverty than were members of the skilled or family class. ${ }^{5}$ The question arises: how have newcomers fared in accessing housing in Vancouver?

Recent research by Hiebert, Mendez, and Wyly indicates that housing trajectories continue to be upward for the majority of newcomers. ${ }^{6}$ Almost 20 per cent of newcomers achieve homeownership within the first six months after arrival; astonishingly 6 per cent of respondents are mortgage-free after this short period of settlement in Canada. These positive outcomes, however, are not shared by all newcomers, a finding acknowledged by the authors of these reports. ${ }^{7}$ While some newcomers are able to move rapidly into home ownership or are living in stable and secure housing, others are "living on the edge" in unsafe, insecure, or crowded conditions within the private rental market. Tenants in particular are identified by Hiebert, Mendez, and Wyly as a group who are not necessarily experiencing a progressive housing career: 20 per cent of all immigrant cohorts who rent are at risk of homelessness (i.e. spending close to, or beyond, 50 per cent of monthly household income on rent). Tenants, research suggests, are increasingly left behind as the gap between owners and renters continues to expand both in Vancouver and in Canada more generally. ${ }^{8}$

Although immigrants overall are faring well in the housing market, therefore, this is not the situation for all newcomers. This paper examines the results of a 2005 study on the circumstances of absolute and relative homelessness among immigrants and refugees in the Greater Vancouver Regional District (GVRD). ${ }^{9}$ In an earlier paper, "Restricted Access: The Role of Social Capital in Mitigating Absolute Homelessness among Immigrants and Refugees in the GVRD," we argued that access to social networks varies according to the mode of entry for immigrants (e.g. skilled immigrants $v s$. refugees). The findings indicate that refugee claimants (RCs) are the most likely of all respondents to "fall between the cracks" of the housing system. Building on the paper by D'Addario, Hiebert, and Sherrell, this paper examines the extent and profile of those experiencing ab- solute and relative homelessness in the GVRD. ${ }^{10}$ The ability to access appropriate and adequate housing may be differentially experienced by immigrants and refugees, and at a finer scale by government-assisted refugees and refugee claimants. ${ }^{11}$ What emerges from our research is a portrait of extremely precarious housing conditions amongst claimants in the GVRD.

\section{Literature Review: Barriers to Housing for Immigrants and Refugees}

Finding adequate housing is a kind of barometer indicating the degree of successful incorporation into a new society. Therefore, understanding the housing experiences of newcomers is an important first step in assessing the different levels of incorporation of new Canadians. For many newcomers, finding appropriate and adequate housing marks the first basic step towards settlement. However, as noted by Chambon et al., Canadians do not have equal access to adequate accommodation. ${ }^{12}$ Moreover, even similar groups of people in similar circumstances vary in their access to the stock of available housing.

\section{Financial Obstacles}

There is a large literature contending that, upon arrival, immigrants earn less than the average Canadian-born person, but that, over time, this gap narrows. This process, also known as "economic assimilation," may no longer be a pervasive reality in Canada, especially among new immigrant cohorts. Although immigrants entering Canada during the 1970s have nearly reached economic parity with the average Canadian-born citizen, subsequent cohorts experience both a lower relative income upon entering Canada and a delayed catch-up period. ${ }^{13}$ These findings are roughly consistent for both men and women immigrants entering during the same time period. Further, the same research shows that even well-educated immigrants share this economic disadvantage. Picot explains that educated immigrant males arriving during the 1970s entered the Canadian labour market earning 82 per cent of the earnings of the average male Canadian. ${ }^{14}$ By the 1990s, new immigrant males earned only 50 per cent of their counterparts. The trend for educated women is similar. Pendakur and Pendakur extend the general story of income dynamics into the labour market, and show that recent immigrants earn wages well below the Canadian average. ${ }^{15}$ In Vancouver, the average Canadian-born annual income was $\$ 26,213$ in 1991 , compared with $\$ 18,208$ earned by immigrants of less than ten years' stay in Canada.

Between 1980 and 2000, the proportion of immigrant family incomes that fell below the low-income cut-off (LICO) has risen considerably. ${ }^{16}$ Although the percentage 
of immigrant families living below the cut-off rose from 24.6 per cent in 1980 to 35.8 per cent in 2000 , the corresponding figures for the Canadian-born declined from 17.2 in 1980 to 14.3 per cent in 2000. Poverty, once largely composed of Canadian-born citizens in 1980, is now predominantly associated with visible minorities and new immigrants (and Aboriginal Peoples and women, especially single mothers).

In 1995, 30 per cent of immigrants residing in urban areas were living below the poverty line, compared with 21.6 per cent of Canadian-born residents. ${ }^{17}$ Furthermore, poverty levels dropped for those who have been residents of Canada a long time: those arriving in Canada prior to 1986 had a poverty rate of 19.6 per cent, compared with 52.1 per cent for those considered recent immigrants (arriving between 1991 and 1996). ${ }^{18}$ As a result of below-average earnings, housing and rent affordability is a chronic issue for new Canadians. In 1996, 21 per cent of immigrant households suffered from "core housing need," which refers to a combination of poor housing quality and problems with affordability. ${ }^{19}$ Recent economic changes have therefore had uneven social consequences, and have been especially hard on immigrants. These financial setbacks translate into difficulty accessing affordable and adequate housing.

\section{Primary and Secondary Barriers}

Chambon et al. assert housing barriers are experienced on a micro scale by the individual (or household unit), but are the result of macro-level dynamics. ${ }^{20}$ The authors separated these obstacles into what they defined as primary and secondary barriers. The former include characteristics that are difficult if not impossible to alter, such as skin colour, race, gender, and ethnicity, while the latter include barriers that can be altered and often do change over time, including language and knowledge of institutions. Extending this argument Hulchanski asserts that because primary barriers such as ethnicity, race, and gender all play an integral role in shaping access to the basic necessities in society full incorporation may not be attained by many newcomers. ${ }^{21}$ Structural barriers, such as high rent prices, lack of social housing, long waiting lists, and low vacancy rates, are intersected by reduced social assistance, legislation that generally favours landlords, and the lack of political intervention in housing crises with micro barriers to compromise access to housing for newcomers. The multiple sites of disadvantage faced by immigrants and refugees result in "differential incorporation," which refers to unequal opportunities faced by particular groups. ${ }^{22}$ This differential incorporation increases the likelihood that immigrants, refugees, and asylum claimants will experience housing stress and/or homelessness.
Recent research by Murdie and Teixeira describes immigrant and refugee strategies to find affordable housing. ${ }^{23}$ In addition to cost, many immigrants experience additional barriers related to the size of their households. Rental accommodations, both private and public, are not designed for large families. The size of affordable dwellings poses concern for many immigrant families owing to larger than (Canadian) average family sizes. While 20 per cent of immigrants live in households of five or more members, this compares to 10 per cent of non-immigrant households. ${ }^{24}$ Research conducted by Miraftab revealed that many refugees felt obligated to be dishonest about the size of their family in order to negotiate a contract. ${ }^{25}$ Family members were later smuggled in after accommodations were attained. ${ }^{26}$ The consequence is often overcrowding, since rental apartments are generally limited to smaller households. In addition, immigrants face the potential for eviction if they are caught hiding additional family members. In these situations families are subject to frequent moves, placing greater financial strain on the household and creating a susceptibility to psychological problems.

In many cases the barriers that newcomers face in the housing market cannot easily be overcome. The reality is that newcomers are significantly more at risk of living in poverty than the average Canadian-born person. Moreover, rising levels of poverty among immigrants may consequently imply rising levels of homelessness for these same groups.

\section{Findings: If Not on the Streets or in the Shelters, Then Where?}

While Hiebert, Mendez, and Wyly paint a generally positive picture of the housing situation amongst newcomers six months after arrival, our research focuses upon those experiencing either precarious housing conditions or absolute homelessness. ${ }^{27}$ In some regards the story continues to be positive: findings from the shelter survey reveal that immigrants and refugees are under-represented in Vancouver's shelter population. While immigrants and refugees represent 38 per cent of the population of the GVRD, they account for only 18 per cent of respondents. When Welcome House (the specific institution for government-assisted refugees, or GARs) is removed that number drops to 13 per cent or about one-third of what we may expect given their representation in the larger population. ${ }^{28}$ Further examination, however, reveals that approximately 40 per cent of the non-Canadian born population captured in the shelter survey are refugees. ${ }^{29}$ When we take into consideration that refugees (all categories) account for only 13 per cent of all newcomers to Canada, shelter usage by this group is approximately three times what may be expected. Although some of the results 
can be accounted for by the inclusion of Welcome House in our sample, the results nonetheless begin to illuminate the variability of housing outcomes amongst immigrant and refugee groups. While immigrants as a whole are under-represented, refugees may be over-represented. ${ }^{30}$ Alarmingly, although over 40 per cent of refugees in the shelter survey reported having arrived within the last year, 20 per cent have been in Canada for more than a decade. Shelter usage, then, is not restricted to only recent arrivals but may be indicative of longer-term housing problems.

Disturbingly, anecdotal evidence from shelter staff further reveals the precarious housing situations of many who are not in the shelters. Operators of a housing crisis phoneline in GVRD report increased calls from immigrant and refugee populations in the West End of Vancouver who are "sofa surfing," and suggest many may not be using shelters for cultural reasons. Other information has indicated that when immigrants and refugees have no place to stay, they will stay with family or friends. This may be related to issues of trust, language, the depth of familial and friendship connections, and the desire for a secure place to stay. Given the insecurity of their legal status, claimants may experience obstacles to settlement not faced by others. Unlike GARs, for example, claimants may not receive information necessary to access assistance in locating housing or emergency shelters.

As housing prices continue to increase across the Vancouver Census Metropolitan Area (CMA), low-income groups face increased affordability challenges. ${ }^{31}$ Many of the locations inhabited by respondents in the housing survey (including both immigrants and refugees) also conform to areas in which at least 20 per cent of the population of the census tract is considered to be in the category of low income persons, according to census definitions (see Figure 1). While we cannot definitively assert that our respondents qualify as low income persons the extent to which they particularly refugees - are located within areas of high concentrations of low income persons is striking. With the exception of a small concentration in South Vancouver, the majority of refugees in the housing survey are located in close proximity to either Vancouver's rapid transit line (Skytrain) or other major public transportation routes.

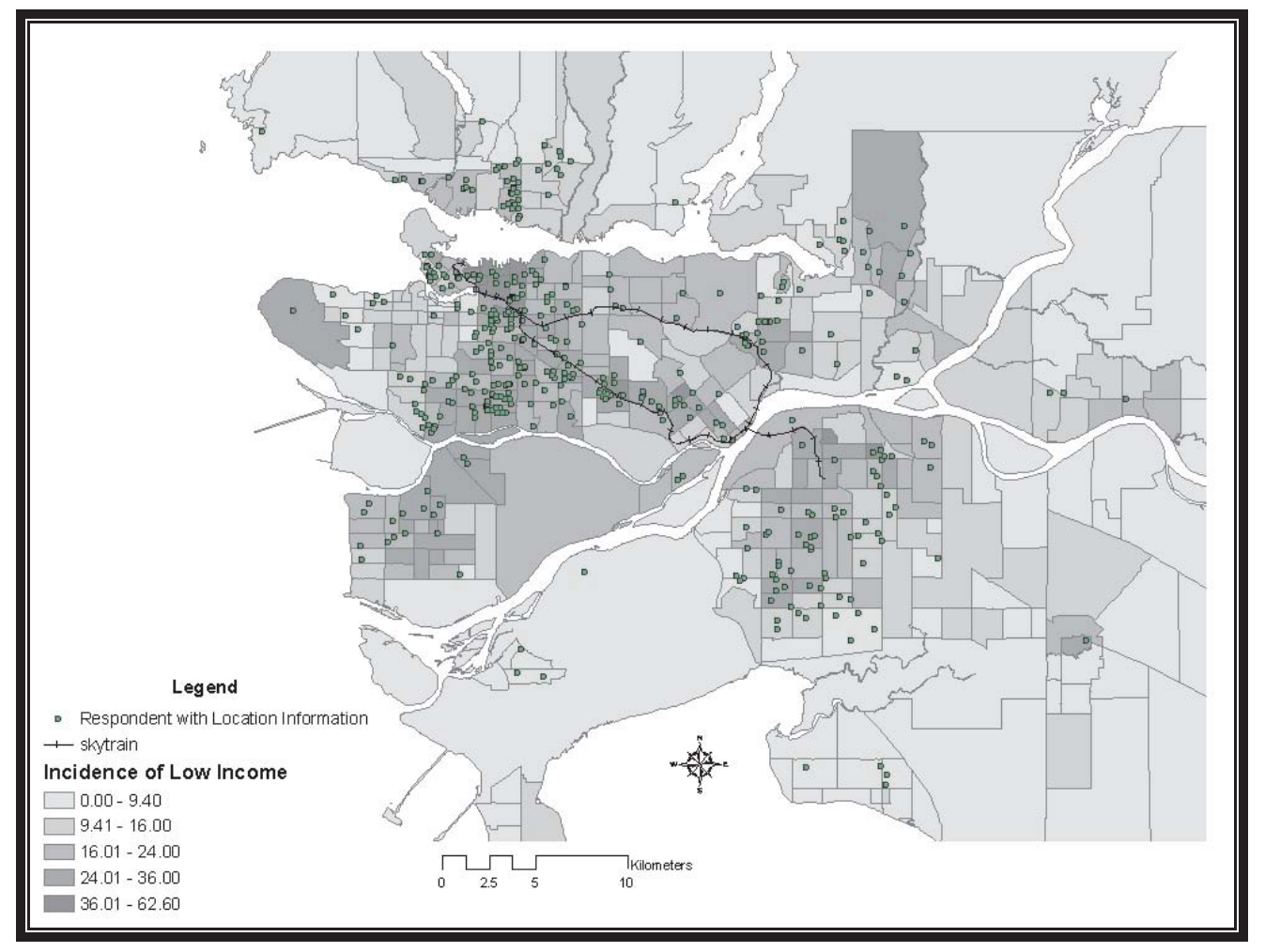

Figure 1: All respondents who provided location information with incidence of low income in census tract

(C) Kathy Sherrell, Silvia D'Addario and Daniel Hiebert, 2007. This open-access work is licensed under a Creative Commons AttributionNonCommercial 4.0 International License, which permits use, reproduction and distribution in any medium for non-commercial purposes, provided the original author(s) are credited and the original publication in Refuge: Canada's Journal on Refugees is cited. 


\section{Living with Low Incomes: Employment and Social Assistance}

Labour force participation amongst respondents across the three sub-studies is marked by un(der)employment and difficulties in obtaining employment. Within the housing survey, both those providing and receiving assistance report high numbers of households in which no one is employed. Of those households receiving help, for example, 35 per cent report having one or more persons employed, while 45.2 per cent of households providing help report having no one employed. We find high numbers of individuals who report providing assistance with housing, yet have no one employed within the household (42.6 per cent for immigrants and 54.5 per cent for refugees). Refugees who are receiving assistance with housing were four times as likely to report having no one employed in the household ( 80.5 per cent) than to report having one or more members of the household being employed (19.5 per cent), while approximately half of immigrant households reported one or more individuals in the household who were employed. Economic insecurity, as measured by high unemployment and low wages, is associated with significant housing affordability problems. $^{32}$

Respondents in both the housing and claimant studies identified a number of barriers to obtaining employment which are consistent with the wider literature. ${ }^{33}$ Problems with recognition of foreign credentials, lack of fluency in English, and the elusive need for Canadian experience all emerged as factors influencing respondents' ability to gain employment. In order to gain a foothold in the labour market, for example, claimants reported having been required to volunteer and/or having been placed at the bottom of the labour market regardless of their skill and education level. Lack of English language proficiency hinders ability of newcomers to obtain employment - a situation that is aggravated for claimants by their inability to access English language classes. ${ }^{34}$

For claimants, these difficulties in obtaining employment are compounded by their assignment of a Social Insurance Number (SIN) beginning in "9." Both key informants and claimants alike identified this visual cue - which marks the bearer as a temporary visitor to Canada - as the major barrier to obtaining employment. While informants spoke of the need to eliminate this marker, claimants spoke of its effects on their attempts to obtain employment. For some, discrimination owing to SIN tagging resulted in not being asked to fill out personal information on applications, while others were not called back for interviews. A claimant from Eritrea recounted his experiences:
There was a job in Coquitlam and everything was great. They showed me what to do, they told me how much they pay me, everything. And then they asked me for my SIN number and it says '9.' "What's this, are you new?". .. if you are new it's terrible.

Unfortunately, the effects of SIN tagging extend beyond the claim period. Because individuals retain the " 9 " on their SIN until permanent residence is obtained, the individual is marked as temporary even after the Immigration and Refugee Board has accepted his or her claim. Discrimination owing to status as a temporary visitor to Canada, then, continues even after a positive determination results in the right to apply for permanent residence.

Access to employment, however, does not preclude the possibility of experiencing even the most absolute forms of homelessness. "Rooflessness" and dependence on emergency shelters is a real possibility even for those with some sort of employment. Although self-reported it is significant that almost one-quarter of all respondents staying in shelter reported some form of employment (full-time, part-time, or casual). Employment was the second most prevalent form of income among immigrants and refugees in the shelter survey. Difficulties in obtaining employment mean newcomers may remain dependent on welfare.

At the time of our research basic welfare provisions ranged from $\$ 510$ per month for single, employable recipients to higher amounts depending on the structure of the family and number of individuals within it. ${ }^{35}$ While many claimants were dependent upon government aid at least during the initial stages after arrival (thirty-two of thirty-six respondents in our claimants study), some may be deemed ineligible for welfare as result of an initial negative decision of their case by the Immigration and Refugee Board. ${ }^{36}$ This was the case for two of the thirty-six claimants interviewed in our study. Ineligibility for welfare assistance has wider implications on an individual's ability to access emergency shelter as the majority of shelter beds in the Vancouver area require Ministry of Human Resources (MHR) vouchers. Those without proper documentation, or who do not qualify under criteria established by MHR, are hindered in their efforts to access emergency shelters by a lack of available emergency beds that do not require Ministry vouchers. ${ }^{37}$ Very recent arrivals, including those lacking proper documentation, may not be eligible to access even the most rudimentary form of emergency shelters. Additionally, the perceived fear of deportation may prevent claimants from accessing emergency shelters.

Those reliant on social assistance in Vancouver are experiencing a critical housing affordability problem: rents have increased but the basic welfare allowance has not. ${ }^{38}$ Unaffordable rental rates are cited by claimants as the most 
common barrier to accessing housing. In 2005 the average rents for bachelor suites and one-bedroom units in Vancouver CMA were $\$ 678$ and $\$ 788$ respectively. ${ }^{39}$ While rents have kept pace with inflation, social assistance rates have not. According to the National Council of Welfare the 2005 poverty line (measured by LICO) - is $\$ 20,778$ (before-tax) or $\$ 17,219$ (after-tax) for single employable persons in the province of British Columbia. Given 2005 welfare rates of $\$ 6,120$ per year, this represents approximately 29.5 per cent (before tax) or 35.5 per cent (after tax) of the poverty line. ${ }^{40}$ For single, employable people, the cost of renting a bachelor suite - at the average price of $\$ 678$ per month - exceeds annual welfare assistance by over $\$ 2,000$ per year, necessitating a search for the cheapest accommodations available or doubling up even within small spaces.

Low vacancy rates compound the difficulties associated with high rental rates and insufficient (welfare) incomes. In 2005, the average vacancy rate in Vancouver CMA was 1.4 per cent, well below the provincial average of 1.9 per cent. ${ }^{41}$ While these vary across the CMA, the average vacancy rate within the City of Vancouver (where most of the rental units exist) was 0.7 per cent. Higher rent increases in larger units function to increase vacancy rates in these units as households seek to maximize their housing dollars, e.g. by choosing smaller units. Consequently, vacancy rates are highest among bigger units, while those for smaller units remain low (e.g. 2.2 per cent for units with more than three bedrooms compared to 1.0 per cent for bachelor suites). Vacancy rates continue to be lowest among those units that are in greatest demand by claimants (e.g. bachelor units, one-bedroom suites).

The rent-income discrepancy is evident in the extent to which respondents in the housing and claimant studies reported having experienced affordability problems for at least some part of their time since arrival. According to Canada Mortgage and Housing Corporation (CMHC) standards, housing is considered affordable if it accounts for no more than 30 per cent of gross household monthly income. Those spending beyond 30 per cent of monthly household income on housing are considered to be experiencing housing stress, while households allocating more than of 50 per cent are experiencing critical housing stress. The affordability challenges experienced by respondents in our study was staggering: at the time of the study 65 per cent of those not receiving help in the housing study and over 75 per cent of individuals in the claimant study did not meet affordability standards established by CMHC. ${ }^{42}$ Respondents in the housing study who do not meet affordability standards are equally distributed between those experiencing housing stress and critical housing stress. Astonishingly, over 60 per cent of respondents who report having provided assistance are at-risk of homelessness themselves (i.e. they spend at least 31 per cent of income on housing); one-quarter of respondents providing assistance are themselves experiencing critical housing stress.

For claimants the situation is even more dire: when asked to reflect on rent payments as a percentage of total monthly household income for both their initial (after arrival) and current housing, all respondents in the claimant study reported having experienced critical housing stress for at least some part of their housing experience in Canada. Initially, all respondents reported having spent over 51 per cent of monthly household income on housing. Four of the thirtysix respondents initially spent 75 per cent or more of their household income on housing. At the time of the interview, which was approximately one year after receiving a positive decision on their claims, the housing situation of claimants had improved somewhat: almost 40 per cent of respondents (fourteen of thirty-six) reported spending less than 50 per cent of household income on housing. Even within those experiencing (critical) housing stress the situation improved slightly with average percentage devoted to rent declining from 65 per cent on arrival to closer to 50 per cent at the time of the study. In spite of modest improvements in affordability, however, it is significant that less than one-quarter of respondents fall within the national affordability standards (defined as spending less than or equal to 30 per cent of monthly household income on housing) one year after the positive decision.

\section{Case Study}

Brenda, a single mother from Congo, has been paying more than 75 per cent of her income on housing since she arrived in Canada in 2003. After staying in two emergency centres for the first three weeks here, Brenda found a one-bedroom apartment in New Westminster. Her rent costs $\$ 660$ a month with an additional $\$ 140$ for her phone bill and utilities. As a single mother, Brenda is entitled to $\$ 845$ plus an additional child benefit of $\$ 246$ a month. Brenda's monthly income totals $\$ 1,091$, while her housing expenses total $\$ 800$. Brenda has been on the waiting list for $\mathrm{BC}$ housing for over one year. She is frustrated that she and her son have to survive on the provisions of his child benefit. Brenda began crying while discussing her situation, she says, "...it's so difficult now...you can't buy food, buy anything. Maybe if you go to the food bank, I can't eat meat, I can't eat food from my country. It's so difficult. I went [to the welfare office] to ask I need some [bus] tickets because I am going to school. They said we don't give tickets. I said how can I find a job if I can't learn English?” 
Devoting a high percentage, or in some cases all, of monthly household income to housing, means little is left over to pay for other basic necessities (including food, clothing, and transportation).

\section{Stonewalled: Barriers to Housing amongst Immigrants and Refugees}

For immigrants and refugees the structural barriers to obtaining housing that are faced by other low income groups - including inadequate shelter assistance rates, high rental prices, long waitlists, and a lack of affordable and accessible housing - may be compounded by a number of barriers specific to their circumstances (e.g. size of families and lack of suitable housing to meet the needs of large families). ${ }^{43}$ Existing literature highlights a number of difficulties experienced by immigrants with limited financial resources; while the difficulties faced by newcomers may be similar to those of other low-income households, unfamiliarity with the Canadian housing markets and lack of English language proficiency exacerbate these problems. ${ }^{44}$ Legal status may aggravate the situation, as well.

Respondents in the housing survey were provided with a list of barriers to accessing housing (including openended responses) and were asked to indicate any/all difficulties they had experienced. Immigrants and refugees alike both identified language and size of family as the greatest obstacles in finding housing. The inability to communicate proficiently with landlords due to limited English facility raises a barrier for newcomers not necessarily experienced by others in the aggressive Vancouver housing market. Refugees (both GARS and RCs) were twice as likely as the total respondent group to cite language as a barrier in accessing housing (76 and 36 per cent respectively). Lack of proficiency in English can increase barriers owing to the potential inability to read classified advertisements or negotiate rental contracts with landlords. Although some newcomers are able to rely upon family or friends for assistance in finding housing (e.g. by acting as interpreters), not all can do this. Claimants are at an increased risk owing both to their ineligibility for English language classes and to limited social networks, at least upon their arrival. ${ }^{45}$

Size of families, as well as number and age of children, were identified as additional barriers by immigrants and refugees alike. Thirty-four per cent of refugees in the housing study cited size of family as a barrier, while a number of claimants raised this issue spontaneously in the individual interviews. Difficulties in obtaining adequately sized housing owing to a lack of affordable units of sufficient size and unwillingness of landlords to ignore occupancy standards may be compounded by policies prohibiting children.
Landlords were reportedly unwilling to rent to families with children because of increased wear and tear and/or concerns about noise levels. Similarly, Murdie and Teixeira assert that in addition to cost, many immigrants experience additional barriers related to the size of their households. Rental accommodations, both private and public, are not designed for large families. Anecdotal evidence was prevalent of people lying about the number of children in their families in order to obtain housing, as well as instances of overcrowding due to lack of affordable housing of sufficient size for the families involved. ${ }^{46}$ Because larger accommodations are too expensive for claimants who subsist on basic welfare provisions, the only option for many is to seek smaller and more affordable housing units resulting in overcrowding. One male claimant from Sri Lanka commented on the crowded condition of a one-bedroom suite he lived in for six months. He said, "The whole house was filled with beds, like two beds in the room and one bed on the outside."

Beyond the inadequacy of welfare levels and the affordability problem in obtaining adequate housing, some claimants reported facing the issue of welfare discrimination. According to participants, many landlords refuse to accept welfare cheques as payment for rent because it is considered to be an unstable form of income. Because payments are based on recipients' need, they may be suspended at any time, leaving tenants with no way to pay the rent. Landlords told claimants this was too much of a risk.

Finally, claimants may experience additional barriers arising from their precarious legal status. Female claimants, for example, spoke of being subjected to physical and emotional abuse from landlords through constant threats of deportation. One female claimant from Russia reported having been threatened by her landlord who repeatedly stated that she had "tools to kick her out of the country." Those lacking the right to permanent residence may be subjected not only to substandard (housing) conditions but also to exploitation. Lack of social networks and negative media stereotypes about refugee claimants hinder the ability of claimants to access housing. One key informant noted that:

If they are very honest and tell them that they are a refugee claimant, then most probably the landlord won't rent a place to them first. They don't know much about refugee claimants in their mind it's always someone very desperate, no job, maybe experienced violence in their home country or their personality is unknown and also they don't have networks here, so if anything happens they have no other sources to help these tenants. Stigmatization is very serious. 
All but one claimant interviewed in the study spoke of having arrived with no pre-existing social network. Although some are able to tap into ethnic resources after arrival, for example, by approaching someone who looks familiar, this is not the case for all newcomers. Although the ability of newcomers to access social capital was beneficial in avoiding absolute forms of homelessness amongst newcomers in our study, access to social capital is not equal: claimants tend to have less access to social capital. ${ }^{47}$

\section{Isolated and Alone: Facilitating Integration and Access to Housing in the Absence of Information}

When asked about her initial experiences in Vancouver and whether she was notified about any services upon arrival in Canada, a claimant from Mexico said,

no one explained any services...no information what you can get as an immigrant, where to get money, how to get a home; I didn't know about community centres. I feel totally isolated, no language, no family, no hope to go back, no money, no house.

In some cases, lack of information (e.g. about where to go to receive help or how to find accommodations) has resulted in claimants spending the first night or two sleeping on the floor in the airport. The lack of support and information is heightened by gendered cultural expectations. According to one woman from Sri Lanka:

Guys, they can go around and get the information, but ladies, in our country, we are taught that it is scary and especially because we don't know the language and we cannot trust any body and so we cannot find the information right away.

One settlement worker reflected on the capabilities of settlement agencies to provide initial information on housing to claimants. He stated that:

...unfortunately the situation for a lot of settlement workers is that we don't have that many resources to offer in terms of housing. We can't say to our clients, by the way there is this specific way where you go to get all of the information and they will help and give you assistance and inform you about housing and where to go. There is no such thing. [Housing] is an area that the settlement sector has not put that much attention to it, and it's the key thing from the beginning.

While discussing his observations in dealing with claimants, another settlement worker asserted:

...the more supported a refugee claimant is, not only with housing, but with relationships ... they have the support they need to pull it off and they settle in more quickly, generally find jobs more quickly. Refugee claimants are totally disconnected.

For claimants, one of the key needs is information upon arrival (e.g. about how to access housing, etc).

A settlement worker with Chinese claimants expanded upon discrimination based on status:

These refugee claimants don't have many resources to look for other places, and plus these places, the landlord don't like to rent a place to refugee claimants, so they are stuck in a hotel in Chinatown and the living condition is very bad. I heard from my clients that there are mice, and people break in and steal their stuff and also the facilities, shared kitchen and shared bathroom and very it's noisy and also people are gambling ... so the whole environment is not very healthy.

\section{Outcomes: Cockroaches and Cheap Rent...}

The housing conditions in which claimants find themselves can best be described as low-quality and substandard - a place to live but not necessarily a home. Limited resources and difficulties in overcoming barriers force households to seek housing in areas with low rental rates and/or compromise in quality. The crowding, substandard conditions, and safety concerns experienced by claimants come together in alarming combination in one rundown hotel in Chinatown. This accommodation, which is geared to newcomers from China, was the subject of a number of interviewees' stories. A male claimant aged forty-nine from China gave these details:

Things there are in a mess...there were cockroaches everywhere. But the rent was cheap. There were a lot of seniors living there; they are dirty and have a lot of personal belongings, so things are in a mess. A lot of cockroaches. Dirty, stinky.

In the Chinatown example, one washroom and small kitchen are allotted for twenty to thirty people; electricity and heating work sporadically at best. Unhealthy and unsanitary conditions within units are frequently accompanied by multiple safety concerns within the wider neighbourhood. High crime rates, drug abuse, and prostitution are frequently cited concerns. Consequently, claimants are a highly vulnerable and transient population.

One interviewee from Eritrea reported having lived in six places - all of which he characterized as unhealthy - since arriving in 2002, while another from Sri Lanka was in the process of searching for his seventh accommodation in the last two years. In one case the respondent from Eritrea signed a lease without understanding the conditions; in order to avoid losing his damage deposit the respondent 
was forced to live in abhorrent conditions for twelve months. Rather than complaining the claimant waited for the lease to expire and began looking for another place to live. This transience can preclude the stability necessary for successful integration.

\section{Conclusions: Opening the Doors}

As housing prices continue to rise across the Vancouver CMA low income groups are increasingly challenged to procure adequate and affordable housing. For newcomers to Canada a lack of information, barriers to accessing employment and housing, and a lack of language proficiency aggravate the existing income-rent discrepancy brought about by unforgiving housing markets and insufficient (welfare) incomes. The affordability challenges experienced by immigrants and refugees in our study are staggering: many of our respondents are experiencing critical housing stress. While this is true of all groups, claimants face challenges symptomatic of their immigration class. Yet, it is important to note that over 50 per cent of claimants will eventually receive the right of permanent residence. Changes need to be made to make housing more affordable (including higher shelter/social assistance rates), but we also need to think about wider implications of legal status on the procurement of suitable housing. The combination of uncertain legal status, SIN tagging, lack of English language ability, and a dearth of social networks means claimants in particular are exposed to precarious housing situations, a finding that has implications for their eventual integration into Canadian society. For claimants, in particular, these micro barriers intersect with wider structural barriers to preclude full incorporation into Canadian society. If we as a society are to truly welcome refugee groups into Canadian society there is a need to more closely examine the barriers faced by claimants arising from their legal status. Otherwise refugees will remain on the outside looking in, with respect to both affordable housing and Canadian society more broadly.

\section{Appendix A: Methodology}

In approaching this research, and in light of the complexities in defining and enumerating homelessness, we adopted an evidence-based, multiple-points-of-contact study combining qualitative and quantitative approaches. The project was composed of three components, each of which focuses on a particular aspect of homelessness.

1. The first component sought to examine those experiencing absolute homelessness by developing a portrait of the immigrant and refugee populations using emergency shelters and transition houses. This sub-study involved twelve semi-structured interviews with key informants from emergency shelters and second-stage transition houses in the GVRD, and the compilation and analysis of data collected by shelter personnel over seven 24-hour periods between October and December, 2004. In total, we received 261 completed shelter data collection forms.

2. The second component sought to explore the housing situation of refugee claimants who have recently received a positive decision enabling them to stay in Canada. Thirty-six individual interviews were conducted with SRCs in the GVRD. The interviews were semi-structured and explored the housing situation of claimants both before learning of the positive decision and in the first six months since receiving it. In addition, four interviews were conducted with settlement workers.

3. The third component sought to examine the profile and extent of relative homelessness among immigrants, refugees, and refugee claimants. In so doing, we hoped to generate a basic estimate of the "sofa surfing" or "camping out" population among recent immigrants, as well as to identify in-group systems of support through questions about the provision or receipt of housing assistance. This sub-study is mainly focused on the Immigrant and Refugee Housing Survey (IRHS), which was conducted on October 4-8, 2004. In total, we received 554 completed surveys.

\section{Notes}

1. "Vancouver Real Estate Prices Lead the Nation," CKNW, March 8, 2007, <http://www.cknw.com/news/news_local. $\mathrm{cfm}$ ?cat $=7428109912 \& \mathrm{rem}=60226 \& \mathrm{red}=80110923 \mathrm{aPB}$ Iny\&wids $=410 \& \mathrm{gi}=1 \& \mathrm{gm}=$ news_local.cfm $>$ (accessed March 16, 2007); "Real Estate Prices Rise 11.2\% in Year," CBC News, February 15, 2007, <http://www.cbc.ca/canada/britishcolumbia/story/2007/02/15/realestate.html $>$ (accessed March 16, 2007); A. Ford, "Housing Prices Continue to Climb" The Province, April 4, 2007, <http://www.canada.com/the province/news/money/story.html?id=997f0e72-3bd8-4759-afbc -47ce7f0aff70> (accessed April 8, 2007).

2. "Real Estate Prices Continue to Climb."

3. G. Picot, F. Hou, and S. Coulombe, Chronic Low Income and Low-income Dynamics among Recent Immigrants, Analytical Studied Branch Research Paper Series (Ottawa: Statistics Canada, 2007); G. Picot, "The Deteriorating Economic Welfare of Canadian Immigrants," Canadian Journal of Urban Research 13, no. 1 (2004): 25-45; G. Picot and F. Hou, The Rise in Low-income Rates Among Immigrants in Canada, No. 11F0019MIE No.198 (Ottawa: Statistics Canada, 2003); D. Ley and H.A. Smith, "Relations between Deprivation and Immigrant Groups in Large Canadian Cities," Urban Studies 37, no. 1 (2000): 37-62 ; H. A. Smith, "The Evolving Relationship between Immigrant Settlement and Neighborhood Disadvan- 
tage in Canadian Cities, 1991-2001," No. 04-20 (Vancouver: Research on Immigration and Integration in the Metropolis [RIIM], 2004); K. Pendakur and R. Pendakur, The Colour of Money, RIIM No. 96-03 (Vancouver: Joint Centre of Excellence for Research on Immigration and Settlement, 1996).

4. V. Galt, "The New Face of Poverty," Globe and Mail, January 30, 2007; for the full report see Picot, Hou, and Coulombe.

5. Controlling for demographic differences, 27.1 per cent of refugees in the 2000 entering cohort experienced chronic low income compared to 13.4 per cent in the family class and 15.6 per cent in the skilled class. See Picot, Hou, and Coulombe for a more detailed discussion.

6. D. Hiebert, P. Mendez, and E. Wyly, The Housing Situation and Needs of Recent Immigrants in the Vancouver CMA (Ottawa: Canada Mortgage and Housing Corporation, 2007); P. Mendez, D. Hiebert, and E. Wyly, "Landing at Home: Insights on Immigration and Metropolitan Housing Markets from the Longitudinal Survey of Immigrants to Canada," Canadian Journal of Urban Research 15, no.2 (2006): 82-104.

7. Because refugee claimants are temporary residents, their experiences are not captured in large-scale studies such as those by Hiebert, Mendez, and Wyly.

8. Hiebert, Mendez, and Wyly; Mendez, Hiebert, and Wyly; J. D. Hulchanski, "A Tale of Two Canadas: Homeowners Getting Richer, Renters Getting Poorer," in Finding Room: Policy Options for a Canadian Rental Housing Strategy (Toronto: CUCS Press, 2004), 81-88; J. D. Hulchanski, "How Did We Get Here? The Evolution of Canada's 'Exclusionary' Housing System," in Finding Room: Policy Options for a Canadian Rental Housing Strategy (Toronto: CUCS Press, 2004), 189-194.

9. See Appendix A for a brief explanation of the methodology. For a full discussion of the methodology and findings of the report see D. Hiebert, S. D'Addario, and K. Sherrell, The Profile of Absolute and Relative Homelessness among Immigrants, Refugees, and Refugee Claimants in the GVRD (Vancouver: Multilingual Orientation Service Association for Immigrant Communities, 2005), <http://www.mosaicbc.com/The_Profile_of_Absolute_and_Relative_Homelessness.pdf $>$ (accessed May 2005).

10. S. D'Addario, D. Hiebert, and K. Sherrell, "Restricted Access: The Role of Social Capital in Mitigating Absolute Homelessness among Immigrants and Refugees in the GVRD," Refuge 24, no. 1 (2007): 107-115.

11. For the sake of clarity "GARs" is used to denote governmentassisted refugees, while "claimants" denotes successful refugee claimants. The term "refugees" is understood to include both GARs and claimants.

12. A. Chambon, D. Hulchanski, R. Murdie, and C. Teixeira, "Access to Housing in a Canadian City: Experiences of Three Immigrant Groups" (paper, Urban

Affairs Association Conference, Toronto, 1997).

13. After spending more than twenty years in Canada, the 1970s male cohort earned 97 per cent of the earnings of the "like" Canadian (adjusting for age, education, etc.). Immigrants arriving during the 1980 s earned approximately 85 per cent of incomes earned by their Canadian-born counterparts after sixteen to twenty years in Canada. Finally, the 1990s cohort earned 70 per cent of the average Canadian-born income, after six to ten years in Canada; Picot. See also Pendakur and Pendakur.

14. Ibid.

15. Ibid.

16. Picot.

17. K. Lee, Urban Poverty in Canada (Ottawa: Canadian Council on Social Development, 2000).

18. Ibid.

19. Pendakur and Pendakur.

20. Chambon et al.

21. J. D. Hulchanski, "Immigrants and Access to Housing: How Welcome Are Newcomers to Canada?" in Metropolis Year II: The Development of a Comparative Research Agenda, Proceedings of the Second National Conference and of the Thematic Seminar "Housing and Neighbourhood," November 23-26, 1997 (Montreal: 1997), 263-274.

22. Chambon et al.

23. R. Murdie and C. Teixeira, "Toward a Comfortable Neighbourhood and Appropriate Housing: Immigrant Experiences in Toronto," CERIS No. 19 (Toronto: Joint Centre of Excellence for Research on Immigration and Settlement, 2001).

24. Ibid.

25. F. Miraftab, "Sheltering Refugees: The Housing Experience of Refugees in Metropolitan Vancouver, Canada" Canadian Journal of Urban Research 9, no. 1 (2000): 42-57.

26. See also Chambon et al.

27. Hiebert, Mendez, and Wyly. We employ a broad definition of homelessness that includes a range of circumstances from being without permanent shelter (i.e. "rooflessness"), through various forms of relative homelessness, such as "sofa surfing" and crowding. The former definition refers to those people who live without shelter and therefore reside on the streets or rely on public facilities such as emergency shelters (often defined as "absolute homelessness"), while the latter refers to those people who possess shelter, but are subject to substandard, unsafe, and/or temporary conditions. T. Peressini, L. McDonald, and D. Hulchanski, Estimating Homelessness: Towards a Methodology for Counting the Homeless in Canada (Ottawa: Canada Mortgage and Housing Corporation, 1991), $<$ http://www.cmhc-schl.gc.ca/en/imquaf/ho/ho_005.cfm>. Defining homelessness has always proved to be contentious, and the particular definition adopted in a study will influence results, especially in terms of the number of people included in the category of homeless. Further, the definition chosen will affect policy, since the scope of provisions and assistance is directly linked to the scale of homelessness that is identified. See also G. Valentine, Social Geographies: Space and Society (Harlow, England: Prentice Hall, 2001); A. Veness, "Neither Homed nor Homeless: Contested Definitions and the Personal Words of the Poor," Political Geography 12, no. 4 (1993): 319-340.

(C) Kathy Sherrell, Silvia D'Addario and Daniel Hiebert, 2007. This open-access work is licensed under a Creative Commons AttributionNonCommercial 4.0 International License, which permits use, reproduction and distribution in any medium for non-commercial purposes, provided the original author(s) are credited and the original publication in Refuge: Canada's Journal on Refugees is cited. 
28. The under-representation of newcomers amongst the absolute homeless population is reinforced by the findings of the 2005 Greater Vancouver Homeless Count.

29. Further, 28 per cent of respondents have become naturalized and as such did not specify their class of origin. Consequently, the number of respondents who arrived as refugees (either government-assisted refugees or refugee claimants) may be even higher than reported. Thirty-six per cent of respondents listed country of last permanent address as being outside of Canada; but we must remember that this includes Welcome House.

30. Although we recognize these results are not necessarily representative of the wider population, anecdotal evidence from shelter workers suggests these findings are consistent with their lived experiences.

31. Juan Pablo Mendez-Gonzalez, "Priced Out: A Profile of Tenant Households and Their Capacity to Enter Homeownership in Metropolitan Canada" (master's thesis, University of British Columbia, 2006).

32. For a more detailed discussion see Damaris Rose and Brian Ray, "The Housing Situation of Refugees in Montreal Three Years after Arrival: The Case of Asylum Seekers Who Obtained Permanent Residence," Journal of International Migration and Integration / Revue de l'intégration et de la migration internationale 2, no. 4 (2001): 493-529.

33. For a more detailed discussion see: H. Krahn, T. Derwing, M. Mulder, and L. Wilkinson, "Educated and Underemployed: Refugee Integration into the Canadian Labour Market," Journal of International Migration and Integration / Revue de l'intégration et de la migration internationale 1, no.1 (2000): 59-84; L. Lo, V. Preston, S. Want, K. Reil, E. Harvey, and B. Siu, Immigrants' Economic Status in Toronto: Rethinking Settlement and Integration Strategies (Full Text Version), 2001, $<$ http://www.metropolis.net> (accessed December 2, 2002); B. Abu-Laban, T. Derwing, H. Krahn, M. Mulder, and L. Wilkinson, The Settlement Experiences of Refugees in Alberta, rev. ed. Study prepared for Citizenship and Immigration Canada. (Edmonton: Prairie Centre of Excellence for Research on Immigration and Integration and Population Research Laboratory, November 15, 1999); N. K. Lamba and H. Krahn, "Social Capital and Refugee Resettlement: The Social Networks of Refugees in Canada," Journal of International Migration and Integration 4, no. 3 (2003): 335-360; V. Preston and G. Man, "Employment Experiences of Chinese Immigrant Women: An Exploration of Diversity," Canadian Woman Studies - les cahiers de la femme 19, no. 3 (1999): 115-122.

34. The exclusion of refugee claimants from formal English language classes means they are dependent on volunteer-run classes that lack standardized levels and focus upon survivallevel English.

35. Under these rates a single parent with one child is entitled to $\$ 845$ per month, while a couple with two children receives $\$ 991$ per month. These rates include both basic assistance and shelter allowance. Social assistance rates increased effective April 1, 2007; the impact of these increases is yet to be seen.
36. While access to welfare is not an immigration issue per se, there exists a need to ensure that those individuals progressing through all stages of the refugee determination system have access to basic financial assistance.

37. Key informants suggest those without status do not qualify for shelters and as such may move from transition house to transition house until they eventually have no place to stay and end up on the streets or in exploitative relationships.

38. In April 2007 the Government of British Columbia increased basic shelter rates by $\$ 50$ for individuals and $\$ 100$ for families.

39. Average rents for two bedrooms and three bedrooms or more were $\$ 1,004$ and $\$ 1,184$ respectively.

40. "Statistics Canada's After Tax Low-Income Cutoffs for 2005," Ottawa: National Council of Welfare, 2006, http://www. ncwcnbes.net/en/research/povertylines/relatedfactsheets.html>; also "“BC Employment and Assistance Rate Tables," Victoria: Ministry of Employment and Income Assistance, 2006. It is important to note that recipients may be eligible for additional income above and beyond basic welfare rates, including provincial and/or federal tax credits. For a single, employable person in 2005 this represented an additional \$336. Because not all people may receive these benefits, they have not been included in our calculations.

41. "Rental Market Report: Vancouver CMA" (Ottawa: Canada Mortgage and Housing Corporation, 2005).

42. It is important to note that this question was asked only of those respondents not receiving help with housing. Had we asked all respondents what percentage of their household income is spent on housing, we may have received very different responses.

43. These findings echo those in the existing literature; for further discussion see Murdie and Teixeira; Miraftab; Chambon et al.; and J. Zine, Living on the Ragged Edges: Absolute and Hidden Homelessness among Latin Americans and Muslims in West Central Toronto (Toronto: Equinox Research and Consulting Services, 2002).

44. B. Ray, A Comparative Study of Immigrant Housing, Neighbourhoods and Social Networks in Toronto and Montreal (Ottawa: Canada Mortgage and Housing Corporation, 1998); T. Owusu, "Residential Patterns and Housing Choices of Ghanaian Immigrants in Toronto, Canada," Housing Studies 14, no. 1 (1999); R. Murdie, "Pathways to Housing: The Experiences of Sponsored Refugees and Refugee Claimants in Accessing Permanent Housing in Toronto," CERIS Working Paper (Toronto: York University, 2005); Zine.

45. As previously noted, claimants are often restricted to accessing voluntary English language classes which are not standardized and usually represent survival English at best. For a more detailed discussion of claimants access to social capital see D'Addario, Hiebert, and Sherrell.

46. See Miraftab for further discussion of the strategies undertaken by families in light of the lack of accommodations for large families.

47. For a more detailed discussion, see D’Addario, Hiebert, and Sherrell.

(C) Kathy Sherrell, Silvia D'Addario and Daniel Hiebert, 2007. This open-access work is licensed under a Creative Commons AttributionNonCommercial 4.0 International License, which permits use, reproduction and distribution in any medium for non-commercial purposes, provided the original author(s) are credited and the original publication in Refuge: Canada's Journal on Refugees is cited. 
Kathy Sherrell is a doctoral candidate in the Department of Geography at the University of British Columbia. Her most recent research examines the housing trajectories of governmentassisted refugees and refugee claimants in Vancouver and Winnipeg.

Silvia D'Addario is a doctoral candidate in the Department of Geography at York University. Her most recent research examines the intersections of home and work for recent transnational immigrants in Toronto's suburbs.

Daniel Hiebert is a professor in the Department of Geography at the University of British Columbia, and the Co-Director of Metropolis British Columbia (formerly the Vancouver Centre of Excellence for Research on Immigration and Integration -
RIIM). His most recent research examines the economic integration of immigrants in Canada and the situation of immigrants in Canada's housing market.

This research was generously funded by the National Secretariat on Homelessness, Canada Mortgage and Housing Corporation, and Metropolis British Columbia. The authors wish to thank Sherman Chan, Director of Settlement Services at the Multilingual Orientation Service Association for Immigrant Communities (MOSAIC) in Vancouver, who is the Principal Investigator on the project, as well as the members of our Research Advisory Committee and participants in the research. 